\title{
Ślina jako płyn biologiczny w diagnostyce chorób ogólnoustrojowych - przegląd piśmiennictwa
}

\author{
Saliva as a biological fluid in diagnostics of systemic diseases \\ - a literature review
}

Klinika Stomatologii Zachowawczej i Endodoncji,

Uniwersytet Medyczny im. Karola Marcinkowskiego w Poznaniu

DOI: http://dx.doi.org/10.20883/df.2018.31

\begin{abstract}
STRESZCZENIE
Ślinę jako materiał diagnostyczny wykorzystywano do monitorowania chorób jamy ustnej - m.in. próchnicy, zapaleń przyzębia - a obecnie jej zastosowanie rozszerza się do kontroli stanu zdrowia całego organizmu. Nowe obiecujące technologie molekularne ostatniego dziesięciolecia skupiają się na analizie białek, jak i kwasów nukleinowych zawartych w ślinie. W 2008 r. zidentyfikowano i skatalogowano skład ślinowego proteomu zawierającego wówczas 1166 białek. W transkryptomie wykryto ponad 3000 rodzajów mRNA oraz odkryto m.in. nowe rodzaje microRNA czy IncRNA. Ślina posiada ogromny wachlarz możliwości w diagnostyce wielu chorób ogólnoustrojowych - onkologicznych, endokrynologicznych, kardiologicznych, autoimmunologicznych, neurologicznych czy też zakaźnych. Niejednokrotnie nieinwazyjne badanie składu śliny pozwoliłoby na wczesne rozpoznanie będące priorytetem dla wyboru skutecznej terapii oraz lepszego rokowania.
\end{abstract}

Słowa kluczowe: choroby ogólnoustrojowe, diagnostyka, marker, ślina.

\section{ABSTRACT}

Saliva has been used as a diagnostic material for monitoring oral diseases - e.g. dental caries, periodontal disease - and it is becoming more and more commonly used for monitoring systemic health. New promising molecular technologies within the last decade focused on salivary protein and nucleic acid analysis. In 2008 , the components of salivary proteome, which included 1166 proteins, were identified and catalogued. More than 3000 types of mRNA were found in the transcriptome and e.g. new types of microRNA and IncRNA were discovered. Saliva is associated with a remarkable range of possibilities in the diagnostics of several systemic disorders, including oncological, endocrine, cardiovascular, autoimmune, neurological and infectious diseases. Non-invasive tests used in order to determine its composition could enable early detection of a disease, which constitutes the key factor for the choice of effective therapy and better prognosis.

Keywords: systemic diseases, diagnostics, marker, saliva.

\section{Wstęp}

Ślina jest opalizującym płynem biologicznym stanowiącym mieszaninę wydzieliny 3 par dużych i wielu drobnych gruczołów ślinowych oraz płynu dziąsłowego. Duże gruczoły jako odrębne parzyste narządy o budowie płacikowej są położone poza jamą ustną. Zalicza się do nich ślinianki: przyusznicze, podżuchwowe i podjęzykowe. Drobne gruczoły (ok. 5000) położone są zwykle w błonie podśluzowej. Udział poszczególnych gruczołów ślinowych w wydzielaniu śliny w spoczynku przedstawiono na rycinie 1.

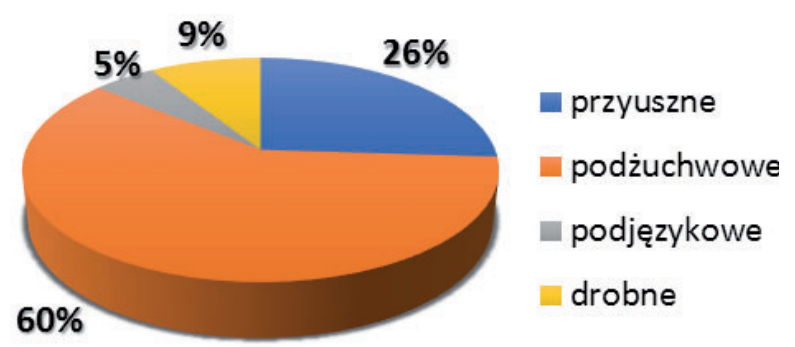

Rycina 1. Udział poszczególnych gruczołów ślinowych w wydzielaniu śliny w spoczynku

Figure 1. Secretion of unstimulated saliva by particular salivary glands 
Odczyn śliny niestymulowanej jest zbliżony do obojętnego (średnie $\mathrm{pH}=6,7$ ), jednakże wraz ze wzrostem szybkości jej wytwarzania staje się bardziej zasadowy (wydziela się wówczas więcej jonów $\mathrm{HCO}_{3}^{-}$). Dobowa objętość wydzielanej śliny wynosi ok. 1-1,5 litra - w spoczynku $0,2-0,3 \mathrm{ml} / \mathrm{min}$, podczas stymulacji $1,5-2,3 \mathrm{ml} /$ min. Wydzielanie śliny posiada podwójną regulację autonomiczną. Podczas pobudzenia układu przywspółczulnego (cholinergicznego) następuje obfite wydzielanie wodnistej śliny, natomiast podczas pobudzenia układu współczulnego (adrenergicznego) gęstej śliny obfitującej w białko, o zmienionym składzie elektrolitowym. Ślina zawiera średnio ok. $99 \%$ wody, a resztę stanowią substancje organiczne i nieorganiczne [1].

Ślina pełni liczne funkcje:

> ochronną - m.in. utrzymanie homeostazy, oczyszczanie poprzez nawilżanie i przepływ, buforowanie, remineralizacja, udział w procesach gojenia,

, trawienną - trawienie (amylaza oraz lipaza), odczucie smaku (tylko rozpuszczone substancje pobudzają receptory komórek kubków smakowych),

, obronną - mechanizmy swoiste (IgA i lgG) i nieswoiste (lizozym, interferon, peroksydazy, histatyny, cystatyny),

> diagnostyczną, co jest tematem przewodnim poniższego opracowania.

Ślina, podobnie jak krew, zawiera liczne enzymy, hormony czy przeciwciała, jednakże nie stanowi jedynie biernego jej przesączu [2]. Wraz z rozwojem nowych technik, takich jak diagnostyka molekularna czy nanotechnologia, mała objętość materiału i niskie stężenia badanych elementów w ślinie przestały być przeszkodą [3]. Ślina jest łatwa do pobrania i to nieinwazyjnie, co eliminuje stres wywoływany u pacjentów podczas pobierania krwi. Pobieranie śliny jest bezpieczne nawet dla mniej wykwalifikowanego personelu medycznego i nie wymaga jak krzepnąca krew - specjalnych warunków przed dostarczeniem do laboratorium [4].

Nowe przyszłościowe technologie molekularne skupiają się na analizie białek, jak i kwasów nukleinowych zawartych w ślinie. W 2008 roku zidentyfikowano i skatalogowano skład ślinowego proteomu. Zawierał on wówczas 1166 białek, z których 914 było wydzielanych przez ślinianki przyuszne, 917 przez ślinianki podżuchwowe i podjęzykowe, a 665 było „wspólnych” [5]. W transkryptomie wykryto około 3000 rodzajów mRNA, z czego 185 mRNA określono jako stały zestaw u każdego zdrowego człowieka [6]. Ponadto odkryto obec- ność microRNA, kodowanego przez geny, jednakże nieulegającego translacji do białek [7]. Obiecującą w rozwoju nie tyle diagnostyki, co terapii jest również, mniej jeszcze poznana farmakogenomika [8]. Rozwiązaniami przyszłości są technologie lab-on-a-chip (LOC) i point-of-care (POC), które miałyby być przenośnymi, zminiaturyzowanymi urządzeniami dającymi natychmiastowe wyniki, w oparciu o zasady konwencjonalnych testów ELISA i/lub hybrydyzacji kwasów nukleinowych [9].

\section{Onkologia}

Ślina posiada ogromny wachlarz możliwości w diagnostyce onkologicznej, gdzie wczesne rozpoznanie jest priorytetowe dla wyboru skuteczniejszej terapii oraz lepszego rokowania. Ślinowe markery wykrywalne w poszczególnych nowotworach przedstawiono $w$ tabeli 1 (z pominięciem nowotworów okolicy głowy i szyi).

Rak trzustki jest jednym z najgorzej rokujących nowotworów, niestety późno wykrywanym, a obiecujące wyniki prowadzonych badań, dzięki rozwojowi diagnostyki dają w przyszłości szansę wykrycia choroby we wczesnych stadiach. Humeau i wsp. [10] wykryli różnice $w$ transkryptomie śliny pacjentów z nieoperowalnym rakiem trzustki, ze zmianami przedrakowymi oraz z przewlekłym zapaleniem trzustki. Z 94 zbadanych miRNA zidentyfikowali podwyższoną ekspresję względem próby kontrolnej, odpowiednio: miR-21, miR-23a, miR-23b i miR-29c, miR-23a i miR-23b oraz miR-210 i let-7c. Natomiast Xie i wsp. [11] odkryli ślinowe IncRNA (długie niekodujące RNA) - HOTAIR i PVT1 ze znacząco wyższą ekspresją w grupie osób z rakiem trzustki.

\section{Endokrynologia}

W ślinie, w przeciwieństwie do krwi, poziomy hormonów steroidowych dotyczą jedynie aktywnej frakcji z pominięciem tej związanej z białkami. Jednakże dobowe zmiany stężeń kortyzolu są zachowane tak jak we krwi. Ślinowy kortyzol może być użyteczny m.in. w diagnozowaniu zespołu Cushinga czy też niewydolności nadnerczy [33].

Wchronicznymstresiezwiązanymzaktywacjąosi podwzgórzowo-przysadkowo-nadnerczowej obserwuje się wzrost ślinowego poziomu kortyzolu $z$ jednoczesnym spadkiem poziomów ślinowych IgA i lizozymu. Z kolei w ostrym stresie, gdzie kluczową rolę odgrywa układ sympatyczno-nadnerczowy, występuje podwyższone stężenie chromograniny A i a-amylazy [34].

Ważnym problemem endokrynologicznym jest cukrzyca, na którą zachorowalność z roku na rok 
Tabela 1. Wybrane nowotwory i ich markery ślinowe

Table 1. Salivary markers of selected neoplasms

\begin{tabular}{|c|c|}
\hline Nowotwór & Biomarkery ślinowe \\
\hline \multirow{2}{*}{ Rak płuca } & mRNA: CCNI, EGFR, FF19, FRS2 i GREB1 [12] \\
\hline & proteiny: kalprotektyna, AZGP1 i HP [13] \\
\hline \multirow{3}{*}{ Rak sutka } & c-erbB-2 (HER2/neu), CA15-3 [14,15] \\
\hline & VEGF, EGF [16] \\
\hline & mRNA: S100A8, CSTA, GRM1, TPT1, GR1K1, H6PD, IGF2BP1 i MDM4 [17] \\
\hline \multirow{2}{*}{ Rak jajnika } & CA125 [18] \\
\hline & mRNA: AGPAT1, B2M, BASP2, IER3 i IL1B [19] \\
\hline Rak przełyku & miRNA: miR-10b*, miR-144, miR-21, miR-451 [20], miR-196a [21] \\
\hline Rak żołądka & proteiny: $1472.78,2936.49,6556.81$ i $7081.17 \mathrm{Da}[22]$ \\
\hline Rak jelita grubego & miRNA: miR-21 [23] \\
\hline \multirow{4}{*}{ Rak trzustki } & IncRNA: HOTAIR i PVT1 [11] \\
\hline & miRNA: miR-21, miR-23a, miR-23b i miR-29c [10], miR-940 [24] \\
\hline & mRNA: KRAS, MBD3L2, ACRV1 i DPM1 [25] \\
\hline & Neisseria elongata, Streptococcus mitis [26] \\
\hline Rak nerkowokomórkowy & profilina-1 [27] \\
\hline \multirow{2}{*}{ Gruczolakorak prostaty } & PSA [28] \\
\hline & miRNA: miR-21 i miR-141 [29] \\
\hline \multirow{2}{*}{ Białaczki } & kwas sjalowy [30], amylaza ślinowa [31] \\
\hline & BCR-ABL, PML-RARa, AML-ETO [32] \\
\hline
\end{tabular}

rośnie, choć u wielu osób pozostaje wciąż nierozpoznana. Szansą mogłoby się stać przesiewowe badanie śliny, która zawiera markery do rozpoznania tej choroby. Na temat powiązań cukrzycy ze składem śliny powstało wiele prac, stąd w obecnym opracowaniu zostaną przedstawione wyniki tylko niektórych z nich.

Harrison i wsp. [35] stwierdzili zwiększone wydzielanie minutowe glukozy do śliny oraz stężenia laktoferyny i IgA, a także zmniejszone wydzielanie śliny u dzieci chorych na cukrzycę typu 1. Reznick i wsp. [36] wykryli wzrost stężenia peroksydazy glutationowej, dysmutazy ponadtlenkowej i całkowitego statusu antyoksydacyjnego, korelujący do ostrości choroby, u pacjentów z cukrzycą typu 1. Cabras i wsp. [37] określili w ślinie dzieci z cukrzycą typu 1 podwyższone poziomy a-defensyn 1, 2 i 4 oraz prozapalnego mediatora S100A9*, jak również obniżone poziomy stateryny, peptydów P-B i P-C oraz histatyn.

Trivedi i wsp. [38] wyznaczyli istotnie podwyższony poziom dialdehydu malonowego, produktu peroksydacji lipidów, u pacjentów z cukrzycą typu 2. Buczko i wsp. [39] zaobserwowali w ślinie chorych na cukrzycę typu 2 z towarzyszącym nadciśnieniem zwiększone stężenia kinureniny i kwasu kinureninowego. Surdacka i wsp. [40] także stwierdzili w ślinie kobiet ciężarnych z cukrzycą przedciążową spadek aktywności enzymów anty- oksydacyjnych (całkowitej zdolności oksydacyjnej, kwasu moczowego, dysmutazy ponadtlenkowej), wskazujący na wzrost produkcji reaktywnych form tlenu i obniżenie obrony antyoksydacyjnej, co potwierdzają inne badania przeprowadzone w poznańskim ośrodku [41, 42].

\section{Kardiologia}

Foley i wsp. [43] u pacjentów po alkoholowej przegrodowej ablacji określili jako istotne w martwicy mięśnia sercowego następujące biomarkery ślinowe: interleukinę-6 (IL-6), metaloproteinazę-9 (MMP-9), rozpuszczalną cząsteczkę adhezji międzykomórkowej (sICAM-1), rozpuszczalny ligand CD40 (sCD40-L), białko C-reaktywne (CRP), troponinę $1 \mathrm{i}$ adiponektynę. Miller $\mathrm{i}$ wsp. [44] ocenili ślinowe stężenia markerów niedokrwienia i martwicy mięśnia serca u pacjentów w ciągu 48 h od zawału. Mioglobina, CRP, TNF-a, MMP-9, mieloperoksydaza, sICAM-1 były podwyższone, a SCD40-L obniżony. Sugeruje się również, że wzrost stężenia endotelialnego inhibitora aktywatora plazminogenu (PAI-1) w ślinie może stanowić czynnik prognostyczny dla wystąpienia ostrego zespołu wieńcowego [45].

Z kolei Qvarnstrom i wsp. [46] wykazali związek pomiędzy zwiększonym stężeniem lizozymu w ślinie a nadciśnieniem, mogącym być początkiem problemów związanych z układem sercowo-naczyniowym. 


\section{Nefrologia}

W zaawansowanej przewlekłej niewydolności nerek można w ślinie wykryć znaczną liczbę markerów. Venkatapathy i wsp. [47] otrzymali istotnie wyższe stężenia kreatyniny w ślinie pacjentów z przewlekłą niewydolnością nerek (stadium 4 . i 5.) względem grupy kontrolnej, tym samym stawiając ślinę jako alternatywny wobec krwi i wygodniejszy dla tych chorych materiał diagnostyczny w przebiegu choroby. Savica i wsp. [48] badali pacjentów hemodializowanych oraz pacjentów z różnymi stadiami przewlekłej niewydolności nerek. Uzyskali istotnie wyższe wyniki stężeń fosforanów w ślinie w porównaniu do grupy kontrolnej. Stężenia te dodatkowo korelowały z poziomem fosforanów we krwi oraz GFR, świadcząc o ślinie jako możliwym markerze hiperfosfatemii. Blicharz i wsp. [49] sugerują w swych badaniach wykorzystanie kolorymetrycznych testów paskowych oceniających stężenie azotanów (III) i kwasu moczowego w monitorowaniu hemodializy u pacjentów ze schyłkową niewydolnością nerek. Arregger i wsp. [50] wykazali podwyższony poziom kortyzolu. Do pozostałych markerów można zaliczyć sód, chlorki, a-amylazę czy laktoferynę. Pawlak i wsp. [51] w przypadku uremii zaobserwowali wzrost stężenia kinureniny, 3-hydroksykinureniny i kwasu antranilowego.

\section{Reumatologia}

Zmiany w ślinie występują także w przebiegu chorób o podłożu autoimmunologicznym. Jedną z nich jest zespół Sjögrena objawiający się zredukowaną sekrecją gruczołów ślinowych i łzowych. W badaniu śliny można zaobserwować zwiększone stężenie, m.in. sodu, IgA, przeciwciał anty-Ro i anty-La, laktoferyny, lizozymu, $\beta_{2}$-mikroglobuliny, prostaglandyny E2, IL-6 [52], a-defensyny 1 czy też $\beta$-defensyny 2 [53]. Poziom amylazy i anhydrazy węglanowej VI jest natomiast obniżony [54].

Giusti i wsp. [55] jako pierwsi podjęli się zbadania proteomu ślinowego u pacjentów z twardziną układową. Ocenili, że kilka z protein, takich jak keratyna $6 \mathrm{~L}$, psoriazyna, TPI (izomeraza trifosforanowa) i kompleks Arp2/3, może stanowić istotne markery w diagnostyce i terapii tej choroby.

Prowadzono więcej badań dotyczących reumatoidalnego zapalenia stawów. Nagler i wsp. [56] wykazali podwyższone poziomy całkowitego statusu antyoksydacyjnego (TAS), dialdehydu malonowego, peroksydazy oraz kwasu moczowego, dodatkowo korelujące z ostrością choroby. Hernández i wsp. [57] u chorych z RZS stwierdzili pod- wyższony poziom kallikreiny, a Mirrielees i wsp. [58] interleukiny-1 $\beta$. Sikorska i wsp. [59] zaobserwowali, że zmiany stężenia CRP w ślinie (w przeciwieństwie do IL-6) mogą stanowić użyteczne narzędzie do kontroli aktywności choroby podczas leczenia biologicznego. Zalewska i wsp. [60] wskazali na wzrost stężenia ślinowej $\beta$-glukuronidazy i izoenzymu A N-acetylo- $\beta$-heksozoaminidazy jako markera wczesnego uszkodzenia gruczołów ślinowych w przebiegu RZS.

Zidentyfikowano także różnice w składzie śliny pacjentów z układowym toczniem rumieniowatym. Ben-Aryeh i wsp. [61] podali zwiększone poziomy sodu, wapnia, magnezu, $\lg A$ i $\lg M$ oraz korelację między ślinowym poziomem lgG a surowiczymi przeciwciałami anty-DNA. Zaieni i wsp. [62] stwierdzili istotnie obniżoną aktywność dysmutazy ponadtlenkowej i katalazy względem próby kontrolnej, a Moori i wsp. [63] podwyższone stężenia kwasu moczowego i dialdehydu malonowego z obniżonym stężeniem glutationu.

\section{Neurologia}

Analiza śliny rzuciła nowe światło na diagnostykę w nieuleczalnych dotąd chorobach Alzheimera i Parkinsona, których leczenie polega jedynie na hamowaniu postępu ich objawów. Bermejo-Pareja i wsp. [64] analizowali, używając testu ELISA, poziomy amyloidu $\beta$-40 i 42 w ślinie osób z chorobą Alzheimera, chorobą Parkinsona oraz zdrowych. Wykazali istotny wzrost stężenia amyloidu $\beta-42$ w grupie pacjentów z łagodnie rozwiniętą chorobą Alzheimera w porównaniu do grupy kontrolnej bez demencji. Nie uzyskali istotnych różnic u pacjentów z chorobą Parkinsona ani też w stężeniach amyloidu $\beta-40$. Sugerują ślinowy poziom $A \beta_{42}$ jako obiecujący biomarker do wczesnego wykrywania choroby.

Shi i wsp. [65] badali, używając testu Luminex, poziomy tau, fosforylowanego tau oraz amyloidu $\beta$-42 w grupie pacjentów z chorobą Alzheimera. Uzyskali istotny wzrost stosunku p-tau/tau względem próby kontrolnej. Nie wykryli jednak znaczącego poziomu $A \beta_{42}$. Proponują analizę ślinowych rodzajów tau jako idealny biomarker nawet screeningowy u bezobjawowych pacjentów, co pozwoliłoby uzyskać szersze okno terapeutyczne u osób z wcześnie wykrytą chorobą. Z kolei Carro i wsp. [66] jako potencjalny marker wczesnej choroby otępiennej wskazują laktoferynę. Natomiast Devic i wsp. [67] zaobserwowali tendencję do wzrostu stężenia DJ-1 i spadku a-synukleiny w ślinie pacjentów z parkinsonizmem. 


\section{Choroby zakaźne}

Ślina znajduje również szerokie zastosowanie w diagnozowaniu zakażeń ogólnoustrojowych. W tym celu wykrywa się przeciwciała, antygeny bądź też kwasy nukleinowe zawarte w ślinie osoby zakażonej. Do tej pory w badaniu śliny zidentyfikowano 23 wirusy oraz 14 bakterii [68].

Wśród wirusów są to np. HPV, HSV, CMV, EBV, wirusy zapalenia wątroby, SARS, wirusy wieku dziecięcego (tj. różyczki, świnki i odry), tropikalny wirus Dengue [69], jak również wirus Ebola [70]. Wykrywanie przeciwciał anty-HIV w ślinie pozwala na łatwe stwierdzenie zakażenia, a ponadto ukazuje obronną rolę śliny w tym procesie [71]. Wykrywalne bakterie to m.in. liczne rodzaje Streptococci, Mycobacterium tuberculosis, Helicobacter pylori czy Tre- dzoną gorączką malaryczną oraz dzieci z gorączką o innej etiologii. Wykazali silny wzrost stężeń białek powiązanych z erytrocytami, jak i stanem zapalnym, ale przede wszystkim wykryli 3 swoiste proteiny patogenu (PFL0480w, PF08_0054, PFI0875w) występujące tylko u dzieci chorych na malarię. W przyszłości badanie proteomiczne śliny może stać się konkurencyjne wobec inwazyjnego wykrywania Plasmodium falciparum we krwi, będącego obecnie złotym standardem w diagnostyce malarii.

\section{Inne choroby ogólnoustrojowe}

Przykłady innych markerów ślinowych występujące w chorobach systemowych przedstawiono w tabeli 2.

Tabela 2. Wybrane inne choroby ogólnoustrojowe i ich markery ślinowe

Table 2. Salivary markers of other selected systemic diseases

\begin{tabular}{|c|c|}
\hline Choroba & Biomarkery ślinowe \\
\hline Nieswoiste zapalenia jelit & $\begin{array}{l}\text { miR-101 (CD) oraz miR-21, miR-31, miR-142-3p i miR-142-5p (UC) [77]; spadek TAC, albumin i kwasu } \\
\text { moczowego, wzrost TGF- } \beta 1 \text {, NO i LPO [78] }\end{array}$ \\
\hline Celiakia & $\begin{array}{l}\text { tTG IgA [79]; wzrost albumin, peroksydazy i mieloperoksydazy, spadek amylazy, lgA i lgG [80]; } \\
\text { antygliadynowe lgA [81] }\end{array}$ \\
\hline Łuszczyca & CRP, haptoglobina [82]; potas, sAA [83]; TNF- $\alpha$, TGF- $\beta 1$, MCP-1 i IL-1 $\beta$ [84] \\
\hline Mukowiscydoza & sód, chlorki [85], katepsyna-D [86]; obniżona aktywność tromboplastyczna [87] \\
\hline Obturacyjny bezdech senny & markery stresu oksydacyjnego [88] \\
\hline Otyłość & TNF-R1, serpina A12, PAI-1, sCD40, sICAM, TNF-R2, PTH-3 i IL-15 [89-92]; wzrost mieloperoksydazy [93] \\
\hline Zespół metaboliczny & CRP, leptyna, insulina, spadek adiponektyny [94]; kwas moczowy [95] \\
\hline Zaburzenia metabolizmu kości & deoksypirydyna, osteokalcyna [96], HGF, IL-1ß [97] \\
\hline Choroba Pompego (LSD) & wzrost TNF-R1, TNF-R2 i MPO, spadek VEGF i MCP-1 [98] \\
\hline Autyzm & hipofosforylacja stateryn, histatyn i kwaśnych białek bogatych w prolinę [99] \\
\hline Ektodermalna dysplazja & spadek wydzielania śliny i amylazy, wzrost składników nieorganicznych i białek [100] \\
\hline
\end{tabular}

ponema pallidum [72]. W przypadku zakażenia $H$. pylori (będącym czynnikiem ryzyka choroby wrzodowej i gruczolakoraka żołądka) poza przeciwciałami i DNA patogenu stwierdza się w ślinie podwyższone stężenie mucyn MUC5B i MUC7 będących bakteryjnymi glikoproteinowymi receptorami [73].

Z innych drobnoustrojów można w ślinie przykładowo wykryć Candida albicans [74]. W przypadku kandydozy ponadto obserwuje się wzrost stężenia immuglobulin, Hsp70, kalprotektyny, histatyn, mucyn, podstawowych PRPs (białek bogatych w prolinę) czy peroksydaz [75].

$Z$ najnowszych badań wartych większej uwagi wynika, że jest możliwość wykrycia w ślinie infekcji Plasmodium falciparum, odpowiedzialnej za malarię, która jest przyczyną zgonu ponad 650 tysięcy osób rocznie, głównie wśród afrykańskich dzieci. Huang i wsp. [76] badali ślinę dzieci z potwier-

\section{Podsumowanie}

Badania śliny jako alternatywy dla krwi i moczu w diagnostyce medycznej skupiają się obecnie na poszukiwaniu i wykrywaniu rozmaitych markerów, mogących stać się czynnikami prognostycznymi podczas rozpoznawania i terapii chorób ogólnoustrojowych. W świetle przedstawionego przeglądu piśmiennictwa ślina jako materiał biologiczny posiada ogromny potencjał diagnostyczny w wielu dziedzinach medycyny.

\section{Oświadczenia}

Oświadczenie dotyczące konfliktu interesów Autorzy deklarują brak konfliktu interesów w autorstwie oraz publikacji pracy.

Źródła finansowania

Autorzy deklarują brak źródeł finansowania. 


\section{Piśmiennictwo}

[1] Knychalska-Karwan Z. Fizjologia i patologia błony śluzowej jamy ustnej. Lublin: Czelej; 2009, s.17-21.

[2] Rehak NN, Cecco SA, Csako G. Biochemical composition and electrolyte balance of "unstimulated" whole human saliva. Clin Chem Lab Med. 2000;38(4):335-343.

[3] Lee $\mathrm{Y}-\mathrm{H}$, Wong DT. Saliva: An emerging biofluid for early detection of diseases. Am J Dent. 2009;22(4):241-248.

[4] Segal A, Wong DT. Salivary diagnostics: enhancing disease detection and making medicine better. Eur J Dent Educ Off J Assoc Dent Educ Eur. 2008;12(Suppl.1):22-29.

[5] Denny P, Hagen FK, Hardt M, Liao L, Yan W, Arellanno $M$, et al. The proteomes of human parotid and submandibular/sublingual gland salivas collected as the ductal secretions. J Proteome Res. 2008;7(5):1994-2006.

[6] Li Y, Zhou X, St John MR, Wong DTW. RNA profiling of cell-free saliva using microarray technology. J Dent Res. 2004;83(3):199-203.

[7] Park NJ, Zhou H, Elashoff D, Henson BS, Kastratovic DA, Abemayor $E$, et al. Salivary microRNA: Discovery, characterization, and clinical utility for oral cancer detection. Clin Cancer Res Off J Am Assoc Cancer Res. 2009;15(17):5473-5477.

[8] Spielmann N, Wong DT. Saliva: diagnostics and therapeutic perspectives. Oral Dis. 2011;17(4):345-354.

[9] Yeh C-K, Christodoulides NJ, Floriano PN, Miller CS, Ebersole JL, Weigum SE, et al. Current development of saliva/oral fluid-based diagnostics. Tex Dent J. 2010;127(7):651-661.

[10] Humeau $M$, Vignolle-Vidoni A, Sicard F, Martins $F$, Bournet B, Buscail L, et al. Salivary microRNA in pancreatic cancer patients. PLOS ONE. 2015;10(6):e0130996.

[11] Xie Z, Chen X, Li J, Guo Y, Li H, Pan X, et al. Salivary HOTAIR and PVT1 as novel biomarkers for early pancreatic cancer. Oncotarget. 2016;7(18):25408-25419.

[12] Zhang L, Xiao H, Zhou H, Santiago S, Lee JM, Garon $E B$, et al. Development of transcriptomic biomarker signature in human saliva to detect lung cancer. Cell Mol Life Sci CMLS. 2012;69(19):3341-3350.

[13] Xiao H, Zhang L, Zhou H, Lee JM, Garon EB, Wong DTW. Proteomic analysis of human saliva from lung cancer patients using two-dimensional difference gel electrophoresis and mass spectrometry. Mol Cell Proteomics MCP. 2012;11(2):M111.012112.

[14] Streckfus C, Bigler L. The use of soluble, salivary c-erbB-2 for the detection and post-operative follow-up of breast cancer in women: the results of a five-year translational research study. Adv Dent Res. 2005;18(1):17-24.

[15] Streckfus C, Bigler L, Tucci M, Thigpen JT. A preliminary study of CA15-3, c-erbB-2, epidermal growth factor receptor, cathepsin-D, and p53 in saliva among women with breast carcinoma. Cancer Invest. 2000;18(2):101-109.

[16] Brooks MN, Wang J, Li Y, Zhang R, Elashoff D, Wong DT. Salivary protein factors are elevated in breast cancer patients. Mol Med Rep. 2008;1(3):375-378.
[17] Zhang L, Xiao H, Karlan S, Zhou H, Gross J, Elashoff D, et al. Discovery and preclinical validation of salivary transcriptomic and proteomic biomarkers for the non-invasive detection of breast cancer. PLOS ONE. 2010;5(12):e15573.

[18] Chen DX, Schwartz PE, Li FQ. Saliva and serum CA 125 assays for detecting malignant ovarian tumors. Obstet Gynecol. 1990;75(4):701-704.

[19] Lee Y-H, Kim JH, Zhou H, Kim BW, Wong DT. Salivary transcriptomic biomarkers for detection of ovarian cancer: for serous papillary adenocarcinoma. J Mol Med Berl Ger. 2012;90(4):427-434.

[20] Xie Z, Chen G, Zhang X, Li D, Huang J, Yang C, et al. Salivary microRNAs as promising biomarkers for detection of esophageal cancer. PLoS ONE. 2013;8(4): e57502.

[21] Fendereski M, Zia MF, Shafiee M, Safari F, Saneie MH, Tavassoli M. MicroRNA-196a as a potential diagnostic biomarker for esophageal squamous cell carcinoma. Cancer Invest. 2017;35(2):78-84.

[22] Wu Z-Z, Wang J-G, Zhang X-L. Diagnostic model of saliva protein finger print analysis of patients with gastric cancer. World J Gastroenterol WJG. 2009;15(7):865-870.

[23] Sazanov AA, Kiselyova EV, Zakharenko AA, Romanov MN, Zaraysky MI. Plasma and saliva miR-21 expression in colorectal cancer patients. J Appl Genet. 2017;58(2):231-237.

[24] Xie Z, Yin X, Gong B, Nie W, Wu B, Zhang X, et al. Salivary microRNAs show potential as a noninvasive biomarker for detecting resectable pancreatic cancer. Cancer Prev Res (Phila Pa). 2015;8(2):165-173.

[25] Zhang L, Farrell JJ, Zhou H, Elashoff D, Akin D, Park $\mathrm{N}-\mathrm{H}$, et al. Salivary transcriptomic biomarkers for detection of resectable pancreatic cancer. gastroenterology. 2010;138(3):949-957.

[26] Farrell JJ, Zhang L, Zhou H, Chia D, Elashoff D, Akin $D$, et al. Variations of oral microbiota are associated with pancreatic diseases including pancreatic cancer. Gut. 2012;61(4):582-588.

[27] Dudek A, Appleyard L, O'Brien TS, Chowdhury $S$, Champion $P$, Challacombe $B$, et al. Salivary markers in renal cell carcinoma. J Clin Oncol. 2014;32(Suppl.4):489-489.

[28] Shiiki N, Tokuyama S, Sato C, Kondo Y, Saruta J, Mori $Y$, et al. Association between saliva PSA and serum PSA in conditions with prostate adenocarcinoma. Biomark Biochem Indic Expo Response Susceptibility Chem. 2011;16(6):498-503.

[29] Hizir MS, Balcioglu M, Rana M, Robertson NM, Yigit MV. Simultaneous detection of circulating oncomiRs from body fluids for prostate cancer staging using nanographene oxide. ACS Appl Mater Interfaces. 2014;6(17):14772-14778.

[30] Joshi S, Hegde AM, Rai K, Shetty S. Evaluation of salivary sialic acid levels in acute lymphoblastic leukemic children and its correlation with dental caries experience. J Clin Pediatr Dent. 2013;37(3):309-313.

[31] Ashok L, Sujatha GP, Hema G. Estimation of salivary amylase and total proteins in leukemia patients and its correlation with clinical feature and radiographic 
finding. Indian J Dent Res Off Publ Indian Soc Dent Res. 2010;21(4):486-490.

[32] Chen D, Song N, Ni R, Zhao J, Hu J, Lu Q, et al. Saliva as a sampling source for the detection of leukemic fusion transcripts. J Transl Med. 2014;12:321.

[33] Raff H. Utility of salivary cortisol measurements in Cushing's syndrome and adrenal insufficiency. J Clin Endocrinol Metab. 2009;94(10):3647-3655.

[34] Koh DS, Koh GC. The use of salivary biomarkers in occupational and environmental medicine. Occup Environ Med. 2007;64(3):202-210.

[35] Harrison R, Bowen WH. Flow rate and organic constituents of whole saliva in insulin-dependent diabetic children and adolescents. Pediatr Dent. 1987;9(4):287-291.

[36] Reznick AZ, Shehadeh N, Shafir Y, Nagler RM. Free radicals related effects and antioxidants in saliva and serum of adolescents with Type 1 diabetes mellitus. Arch Oral Biol. 2006;51(8):640-648.

[37] Cabras T, Pisano E, Mastinu A, Denotti G, Pusceddu $P P$, Inzitari $R$, et al. Alterations of the salivary secretory peptidome profile in children affected by type 1 diabetes. Mol Cell Proteomics MCP. 2010;9(10):2099_ 2108.

[38] Trivedi S, Lal N, Mahdi AA, Mittal M, Singh B, Pandey $S$. Evaluation of antioxidant enzymes activity and malondialdehyde levels in patients with chronic periodontitis and diabetes mellitus. J Periodontol. 2014;85(5):713-720.

[39] Buczko P, Stokowska W, Górska M, Kucharewicz I, Pawlak D, Buczko W. Tryptophan metabolites via kynurenine pathway in saliva of diabetic patients. Dent Med Probl. 2006;43(1):21-25.

[40] Surdacka A, Ciężka E, Pioruńska-Stolzmann M, Wender-Ożegowska E, Korybalska K, Kawka E, Kaczmarek E, Witowski J. Relation of salivary antioxidant status and cytokine levels to clinical parameters of oral health in pregnant women with diabetes. Arch Oral Biol. 2011;56(5):428-436.

[41] Ciężka E, Pioruńska-Stolzmann M, Surdacka A. Assessment of selected antioxidants in the saliva of pregnant women with pregestational diabetes. Dent Forum. 2011;39(2):31-37.

[42] Ciężka E, Pioruńska-Stolzmann M, Surdacka A. Saliva TAS in pregnant women with pregestational diabetes mellitus. J Dent Res. 2010;89(Spec. Iss. B):abstr. 1751.

[43] Foley JD, Sneed JD, Steinhubl SR, Kolasa J, Ebersole $J \mathrm{~L}$, Lin Y, et al. Oral Fluids that Detect Cardiovascular Disease Biomarkers. Oral Surg Oral Med Oral Pathol Oral Radiol. 2012;114(2):207-214.

[44] Miller CS, Foley JD, Floriano PN, Christodoulides N, Ebersole JL, Campbell CL, et al. Utility of salivary biomarkers for demonstrating acute myocardial infarction. J Dent Res. 2014;93(Suppl.7):72-79.

[45] Dyba J, Lenkowski M, Surdacka A. Evaluating the diagnostic potential of saliva in respect of periodontal disease as well as changes occurring within the endothelium. Dent Forum. 2017;45(1):21-25.

[46] Qvarnstrom M, Janket S, Jones JA, Nuutinen P, Baird $A E$, Nunn ME, et al. Salivary Lysozyme and Prevalent Hypertension. J Dent Res. 2008;87(5):480-484.
[47] Venkatapathy R, Govindarajan V, Oza N, Parameswaran S, Pennagaram Dhanasekaran B, Prashad KV. Salivary creatinine estimation as an alternative to serum creatinine in chronic kidney disease patients. Int J Nephrol. 2014;2014:742724.

[48] Savica V, Calò L, Santoro D, Monardo P, Granata A, Bellinghieri $G$. Salivary phosphate secretion in chronic kidney disease. J Ren Nutr. 2008;18(1):87-90.

[49] Blicharz TM, Rissin DM, Bowden M, Hayman RB, DiCesare C, Bhatia JS, et al. Use of colorimetric test strips for monitoring the effect of hemodialysis on salivary nitrite and uric acid in patients with end-stage renal disease: a proof of principle. Clin Chem. 2008;54(9):1473-1480.

[50] Arregger AL, Cardoso EML, Tumilasci O, Contreras $\mathrm{LN}$. Diagnostic value of salivary cortisol in end stage renal disease. Steroids. 2008;73(1):77-82.

[51] Pawlak K, Domaniewski T, Mysliwiec M, Pawlak D. The kynurenines are associated with oxidative stress, inflammation and the prevalence of cardiovascular disease in patients with end-stage renal disease. Atherosclerosis. 2009;204(1):309-314.

[52] Tishler M, Yaron I, Shirazi I, Yaron M. Saliva: an additional diagnostic tool in Sjögren's syndrome. Semin Arthritis Rheum. 1997;27(3):173-179.

[53] Peluso G, Santis MD, Inzitari R, Fanali C, Cabras T, Messana I, et al. Proteomic study of salivary peptides and proteins in patients with Sjögren's syndrome before and after pilocarpine treatment. Arthritis Rheum. 2007;56(7):2216-2222.

[54] Ryu OH, Atkinson JC, Hoehn GT, Illei GG, Hart TC. Identification of parotid salivary biomarkers in Sjögren's syndrome by surface-enhanced laser desorption/ionization time-of-flight mass spectrometry and two-dimensional difference gel electrophoresis. Rheumatology. 2006;45(9):1077-1086.

[55] Giusti L, Bazzichi L, Baldini C, Ciregia F, Mascia G, Giannaccini $G$, et al. Specific proteins identified in whole saliva from patients with diffuse systemic sclerosis. J Rheumatol. 2007;34(10):2063-2069.

[56] Nagler RM, Salameh F, Reznick AZ, Livshits V, Nahir AM. Salivary gland involvement in rheumatoid arthritis and its relationship to induced oxidative stress. Rheumatology. 2003;42(10):1234-1241.

[57] Hernández CCC, Donadi EA, Reis ML. Kallikreins and kininogens in saliva and plasma of patients presenting with rheumatoid arthritis. Scand J Rheumatol. 2002;31(1):38-40.

[58] Mirrielees J, Crofford LJ, Lin Y, Kryscio RJ, Dawson $\mathrm{DR}$, Ebersole JL, et al. Rheumatoid arthritis and salivary biomarkers of periodontal disease. J Clin Periodontol. 2010;37(12):1068-1074.

[59] Sikorska D, Orzechowska Z, Rutkowski R, Prymas A, Mrall-Wechta $M$, Bednarek-Hatlińska $D$, Roszak $M$, Surdacka A, Samborski W, Witowski J. Diagnostic value of salivary CRP and IL-6 in patients undergoing anti-TNF-alpha therapy for rheumatic disease. Inflammopharmacology. 2018;26(5):1183-1188.

[60] Zalewska A, Szulimowska J, Waszkiewicz N, Waszkiel D, Zwierz K, Knaś M. Salivary exoglycosidases in the detection of early onset of salivary gland invo- 
Ivement in rheumatoid arthritis. Postępy Hig Med Dośw. 2013;67:1182-1188.

[61] Ben-Aryeh H, Gordon N, Szargel R, Toubi E, Laufer D. Whole saliva in systemic lupus erythematosus patients. Oral Surg Oral Med Oral Pathol. 1993;75(6):696-699.

[62] Zaieni SH, Derakhshan Z, Sariri R. Alternations of salivary antioxidant enzymes in systemic lupus erythematosus. Lupus. 2015;24(13):1400-1405.

[63] Moori M, Ghafoori H, Sariri R. Nonenzymatic antioxidants in saliva of patients with systemic lupus erythematosus. Lupus. 2016;25(3):265-271.

[64] Bermejo-Pareja F, Antequera D, Vargas T, Molina JA, Carro E. Saliva levels of Abeta1-42 as potential biomarker of Alzheimer's disease: a pilot study. BMC Neurol. 2010;10:108.

[65] Shi M, Sui Y-T, Peskind ER, Li G, Hwang H, Devic I, et al. Salivary tau species are potential biomarkers of Alzheimer disease. J Alzheimers Dis. 2011;27(2):299305.

[66] Carro E, Bartolomé F, Bermejo-Pareja F, Villarejo-Galende A, Molina JA, Ortiz P, et al. Early diagnosis of mild cognitive impairment and Alzheimer's disease based on salivary lactoferrin. Alzheimers Dement Diagn Assess Dis Monit. 2017;8:131-138.

[67] Devic I, Hwang H, Edgar JS, Izutsu K, Presland R, Pan $C$, et al. Salivary a-synuclein and DJ-1: potential biomarkers for Parkinson's disease. Brain. 2011;134(7):e178.

[68] Malamud D, Rodriguez-Chavez IR. Saliva as a diagnostic fluid. Dent Clin North Am. 2011;55(1):159178.

[69] Poloni TR, Oliveira AS, Alfonso HL, Galvão LR, Amarilla $A A$, Poloni $D F$, et al. Detection of dengue virus in saliva and urine by real time RT-PCR. Virol J. 2010;7:22.

[70] Formenty P, Leroy EM, Epelboin A, Libama F, Lenzi M, Sudeck $\mathrm{H}$, et al. Detection of Ebola virus in oral fluid specimens during outbreaks of Ebola virus hemorrhagic fever in the Republic of Congo. Clin Infect Dis Off Publ Infect Dis Soc Am. 2006;42(11):1521-1526.

[71] Lawrence HP. Salivary markers of systemic disease: noninvasive diagnosis of disease and monitoring of general health. J Can Dent Assoc. 2002;68(3):5.

[72] Baguley SDK, Horner PJ, Maple P a. C, Stephenson L. An oral fluid test for syphilis. Int J STD AIDS. 2005;16(4):299-301.

[73] Silva DG, Stevens RH, Macedo JMB, Hirata R, Pinto $A C$, Alves $L M$, et al. Higher levels of salivary MUC5B and MUC7 in individuals with gastric diseases who harbor Helicobacter pylori. Arch Oral Biol. 2009;54(1):86-90.

[74] Liguori G, Lucariello A, Colella G, De Luca A, Marinelli $P$. Rapid identification of Candida species in oral rinse solutions by PCR. J Clin Pathol. 2007;60(9):10351039.

[75] Malathi N, Mythili S, Vasanthi HR. Salivary diagnostics: a brief review. ISRN Dent. 2014;2014:158786.

[76] Huang H, Mackeen MM, Cook M, Oriero E, Locke E, Thézénas $M L$, et al. Proteomic identification of host and parasite biomarkers in saliva from patients with uncomplicated Plasmodium falciparum malaria. Malar J. 2012;11:178.

[77] Schaefer JS, Attumi T, Opekun AR, Abraham B, Hou J, Shelby $\mathrm{H}$, et al. MicroRNA signatures differentiate Crohn's disease from ulcerative colitis. BMC Immunol. 2015;16(1):5.

[78] Rezaie A, Ghorbani F, Eshghtork A, Zamani MJ, Dehghan $G$, Taghavi $B$, et al. Alterations in salivary antioxidants, nitric oxide, and transforming growth factor- $\beta 1$ in relation to disease activity in Crohn's disease patients. Ann N Y Acad Sci. 1091(1):110-122.

[79] Bonamico M, Nenna R, Montuori M, Luparia RPL, Turchetti A, Mennini $M$, et al. First salivary screening of celiac disease by detection of anti-transglutaminase autoantibody radioimmunoassay in. 5000 Italian primary schoolchildren. J Pediatr Gastroenterol Nutr. 2011;52(1):17-20.

[80] Lenander-Lumikari M, Ihalin R, Lähteenoja H. Changes in whole saliva in patients with coeliac disease. Arch Oral Biol. 2000;45(5):347-354.

[81] Rujner J, Socha J, Barra E, Gregorek H, Madaliński K, Woźniewicz B, et al. Serum and salivary antigliadin antibodies and serum IgA anti-endomysium antibodies as a screening test for coeliac disease. Acta Paediatr Oslo Nor. 1992.1996;85(7):814-817.

[82] Krasteva A, Grozdev I, Ivanova A, Altankova I, Kisselova A, Tsankov N. Psoriatic patients and salivary components. 2009;(2):4.

[83] Bottoni U, Tiriolo R, Pullano SA, Dastoli S, Amoruso GF, Nisticò SP, et al. Infrared saliva analysis of psoriatic and diabetic patients: similarities in protein components. IEEE Trans Biomed Eng. 2016;63(2):379384.

[84] Ganzetti G, Campanati A, Santarelli A, Pozzi V, Molinelli E, Minnetti I, et al. Involvement of the oral cavity in psoriasis: results of a clinical study. Br J Dermatol. 2015;172(1):282-285.

[85] Gonçalves AC, Marson FA de L, Mendonça RM de $H$, Ribeiro JD, Ribeiro AF, Paschoal IA, et al. Saliva as a potential tool for cystic fibrosis diagnosis. Diagn Pathol. 2013;8:46.

[86] Minarowska A, Minarowski L, Karwowska A, Sands $D$, Dabrowska $E$. The activity of cathepsin D in saliva of cystic fibrosis patients. Folia Histochem Cytobiol. 2007;45(3):165-168.

[87] Peker S, Kargul B, Tanboga I, Tunali-Akbay T, Yarat $A$, Karakoc F, et al. Oral health and related factors in a group of children with cystic fibrosis in Istanbul, Turkey. Niger J Clin Pract. 2015;18(1):56.

[88] Tóthová L, Hodosy J, Mucska I, Celec P. Salivary markers of oxidative stress in patients with obstructive sleep apnea treated with continuous positive airway pressure. Sleep Breath Schlaf Atm. 2014;18(3):563570.

[89] Lehmann-Kalata A, Miechowicz I, Korybalska K, Swora-Cwynar E, Czepulis N, Łuczak J, Orzechowska Z, Grzymisławski M, Surdacka A, Witowski J. Salivary fingerprint of simple obesity. Cytokine. 2018;110:174-180.

[90] Surdacka A, Lehmann-Kalata A, Swora-Cwynar E, Korybalska K, Kupczyk B, Czepulis N, Łuczak J, Grzymisławski M, Witowski J. Salivary cardiovascular bio- 
markers in obese patients. J Dent Res. 2016;95(Spec. Iss.):abstr. 0267.

[91] Lehmann-Kalata A, Swora-Cwynar E, Grzymisławski M, Korybalska K, Witowski J, Surdacka A. Concentration of salivary TNF-alpha receptors in obesity. Int Dent J. 2016;66(Suppl. 1):134.

[92] Dąbrowska M, Lehmann-Kalata A, Surdacka A. The impact of obesity on the physicochemical and biochemical changes occurring in the saliva. Dent Forum. 2016;44(1):79-82.

[93] Surdacka A, Lehmann-Kalata A, Ciężka-Hsiao E, Swora-Cwynar E, Korybalska K, Grzelczak J, Czepulis N, Grzymisławski M, Witowski J. Increased levels of salivary myeloperoxidase in obesity. J Dent Res. 2014;93(Spec. Iss. C):abstr. 553.

[94] Goodson JM, Kantarci A, Hartman M-L, Denis GV, Stephens D, Hasturk $H$, et al. Metabolic disease risk in children by salivary biomarker analysis. PLoS ONE. 2014;9(6):e98799.

[95] Soukup M, Biesiada I, Henderson A, Idowu B, Rodeback $D$, Ridpath $L$, et al. Salivary uric acid as a noninvasive biomarker of metabolic syndrome. Diabetol Metab Syndr. 2012;4:14.

[96] McGehee JW, Johnson RB. Biomarkers of bone turnover can be assayed from human saliva. J Gerontol A Biol Sci Med Sci. 2004;59(3):196-200.

[97] Scannapieco FA, Ng P, Hovey K, Hausmann E, Hutson A, Wactawski-Wende J. Salivary biomarkers associated with alveolar bone loss. Ann N Y Acad Sci. 2007;1098:496-497.
[98] Drążewski D, Grzymisławska M, Korybalska K, Czepulis N, Grzymisławski M, Witowski J, Surdacka A. Oral health status of patients with lysosomal storage diseases in Poland. Int J Environ Res Public Health. 2017;14(3):E281.

[99] Castagnola M, Messana I, Inzitari R, Fanali C, Cabras T, Morelli A, et al. Hypo-phosphorylation of salivary peptidome as a clue to the molecular pathogenesis of autism spectrum disorders. J Proteome Res. 2008;7(12):5327-5332.

[100] Lexner MO, Bardow A, Hertz JM, Almer L, Nauntofte $B$, Kreiborg $S$. Whole saliva in X-linked hypohidrotic ectodermal dysplasia. Int J Paediatr Dent. 2007;17(3):155-162.

Zaakceptowano do edycji: 2018-10-16 Zaakceptowano do publikacji: 2018-12-05

\section{Adres do korespondencji:}

Kacper Nijakowski

Klinika Stomatologii Zachowawczej i Endodoncji

Uniwersytet Medyczny im. Karola Marcinkowskiego w Poznaniu

ul. Bukowska 70, 60-812 Poznań

e-mail: kacpernijakowski@interia.pl 